\title{
The estrogen receptor 1 gene affects bone mineral density and osteoporosis treatment efficiency in Slovak postmenopausal women
}

Vladimira Mondockova ${ }^{1}$, Maria Adamkovicova ${ }^{1}$, Martina Lukacova', Birgit Grosskopf $2^{2}$ (D), Ramona Babosova ${ }^{3}$, Drahomir Galbavy ${ }^{4}$, Monika Martiniakova ${ }^{3}$ and Radoslav Omelka ${ }^{1}$

\begin{abstract}
Background: The study investigated the associations of rs9340799:A > G (Xbal) and rs2234693:T > C (Pvull) polymorphisms in the estrogen receptor 1 gene (ESR1) with femoral neck (BMD-FN) and lumbar spine bone mineral density (BMD-LS), biochemical markers of bone turnover, calcium and phosphate levels, fracture prevalence, and a response to two types of anti-osteoporotic therapy in postmenopausal women from southern Slovakia.

Methods: We analysed 343 postmenopausal Slovak women (62.40 \pm 0.46 years). The influence of rs9340799 (AA vs. AG + GG) and rs2234693 ( $T$ vs. TC + CC) genotypes on BMD and biochemical markers was evaluated by covariance analysis adjusted for age and BMI. Binary logistic regression was used to evaluate the genotype effect on fracture prevalence. Pharmacogenetic part of the study included women who received a regular therapy of HT (17ß estradiol with progesterone; $1 \mathrm{mg} /$ day for both; $\mathrm{N}=76$ ) or SERMs/raloxifene (60 mg/day; $\mathrm{N}=64$ ) during 48 months. The genotype-based BMD change was assessed by variance analysis for repeated measurements.

Results: Women with AA genotype of rs9340799 had higher BMD-FN (+ $0.12 \pm 0.57$ of T-score) and BMD-LS $(+0.17 \pm 0.08$ of T-score) in comparison with AG + GG. The rs2234693 polymorphism did not affect any of the monitored parameters. No effect of any ESR1 polymorphisms was found on fracture prevalence. Both types of anti-osteoporotic therapy had a positive effect on BMD improvement in FN and LS sites. Considering the effect of the ESR1 gene within the HT, the subjects with rs9340799/AA genotype showed worse response than those with GG genotype $(-0.26 \pm 0.10$ of BMD-FN T-score; $-0.35 \pm 0.10$ of BMD-LS T-score) and also with AG genotype (- $0.22 \pm 0.08$ of BMD-LS T-score). The rs2234693/TT genotype responded poorer in BMD-LS in comparison with TC ( $-0.22 \pm 0.08$ of T-score) and CC $(-0.35 \pm 0.09$ of T-score). The effect of the ESR1 gene on raloxifene therapy was reported only in BMD-LS. Subjects with rs9340799/AA genotype had a $-0.30 \pm 0.11$ of T-score worse response compared to AG genotype. The rs2234693/TT genotype showed $-0.39 \pm 0.11$ and $-0.46 \pm 0.15$ lower T-scores in comparison with TC and CC genotypes, respectively.

Conclusions: The rs9340799 polymorphism may contribute to decreased BMD in postmenopausal women from southern Slovakia; however, this is not related to higher fracture prevalence. Concurrently, both polymorphisms affected a response to analysed anti-osteoporotic therapies.
\end{abstract}

Keywords: Osteoporosis, ESR1 gene, Polymorphisms, BMD, Fractures, HT, Estradiol, Raloxifene

\footnotetext{
* Correspondence: birgit.grosskopf@biologie.uni-goettingen.de

${ }^{2}$ Institute of Zoology and Anthropology, Georg-August University, Göttingen,

Germany

Full list of author information is available at the end of the article
}

(c) The Author(s). 2018 Open Access This article is distributed under the terms of the Creative Commons Attribution 4.0 International License (http://creativecommons.org/licenses/by/4.0/), which permits unrestricted use, distribution, and reproduction in any medium, provided you give appropriate credit to the original author(s) and the source, provide a link to the Creative Commons license, and indicate if changes were made. The Creative Commons Public Domain Dedication waiver (http://creativecommons.org/publicdomain/zero/1.0/) applies to the data made available in this article, unless otherwise stated. 


\section{Background}

Osteoporosis is a common disease, characterized by reduced bone mass, defects in the microarchitecture of bone tissue, and an increased risk of fragility fractures [1]. The presence of fractures together with bone mineral density (BMD) measurements forms the basis of diagnostic techniques that guide targeted intervention strategies. The etiology of osteoporosis is multifactorial in which a polygenic background is modulated by the integrated effects of hormonal, environmental and nutritional factors. Although many environmental factors play an important role in BMD variation, genetic influences account for $60-85 \%$ of individual variance. So far, genetic studies have revealed candidate genes included in the regulation of BMD and in the osteoporosis progression [2-4]. Estrogen deficiency represents a major mechanism of the rapid bone loss in postmenopausal women. Interactions of estrogens with the receptors in target cells of bone and other tissues regulate growth and bone development, acquisition of peak bone mass, bone metabolism and inhibition of bone loss [5]. Therefore, the gene encoding estrogen receptor 1, one of two mediators of estrogen action, has been considered as an important candidate for the determination of osteoporosis risk [6, 7]. The principal role of the ESR1 gene in skeletal maintenance has recently been confirmed using mice with targeted deletion of ESR1 from specific bone cells and their precursors. Lack of the estrogen receptor in osteoblast progenitor and precursor cells affected the periosteum while the absence of the receptor in differentiated osteoblasts, osteocytes, and osteoclasts resulted in reduced cancellous bone mass [8]. Genetic screening of the ESR1 gene locus has revealed several polymorphic sites. The most widely studied are rs2234693: T $>C$ (PvulI), rs9340799:A > G (XbaI) polymorphisms in intron $\mathrm{I}$, and the (TA)n repeat polymorphism within the promoter region of the gene [6]. Several studies showed a relationship between low number of TA repeats and increased fracture risk or BMD in different populations $[9,10]$. Within the rs2234693 and rs9340799 polymorphisms, the results have not always been consistent in different population analyses. However, despite conflicting results, associations of rs2234693 and rs9340799 polymorphisms with BMD have been found in some studies [4, 11-15].

Considering the mechanisms of drug action within specific treatment procedures, such as hormone therapy (HT) or selective estrogen receptor modulators (SERMs) application, the genetic variability in the ESR1 gene may also have important pharmacogenetic implications. The HT is a treatment commonly used to relieve symptoms and some undesirable consequences of menopause including osteoporosis. Exogenous estrogens also belong to the primary osteoporosis prevention in postmenopausal women, as these agents reduce the risk of vertebral and hip fractures [16]. SERMs are used for prevention and treatment of postmenopausal osteoporosis and breast cancer prevention in high-risk postmenopausal women with osteoporosis [17]. Raloxifene, a member of SERMs, simulates estrogen action on the skeletal system through agonistic binding to estrogen receptors without the negative effects on breast and endometrium [18]. As in the case of association studies, the results of pharmacogenetic ones have not always been consistent. Positive effects of TT genotype on fracture risk [19] and BMD [12, 20, 21] were found in different populations. In addition to HT and SERMs, other currently approved therapies for osteoporosis include bisphosphonates (BPs), applications of vitamin D derivates, parathyroid hormone and teriparatide (a recombinant human parathyroid hormone), calcitonin, strontium ranelate, and anti-RANK ligand monoclonal antibodies [22]. Response to drugs can be affected by many factors, such as sex, age, ethnicity, lifestyle, and concomitant diseases or drug therapy. The individual variation of response to anti-osteoporotic treatments ranges from good to little response or nonresponse (estimated proportion from 5 to $10 \%)$, and it may be due to individual genetic factors or environmental influences that could interfere with drug dynamics and kinetics [23]. Common variations in the human genome are today considered as the most important cause of variable drug responses [18].

The aim of this study was to analyse the associations of rs2234693 and rs9340799 polymorphisms in the ESR1 gene with BMD, biochemical markers of bone turnover, calcium and phosphate levels, fracture prevalence, and a response to two types of anti-osteoporotic therapy in postmenopausal women from southern Slovakia.

\section{Methods \\ Studied population}

Our study included 343 postmenopausal women from southern region of the Slovak Republic aged from 45 to 85 years $(62.40 \pm 0.46$ years $)$ and monitored under the basic diagnostic screening for osteoporosis. Women were selected according to strict inclusion criteria. We excluded women with serious internal, endocrine, chronic and hereditary diseases, patients treated with certain medicaments (glucocorticoids, hormones) and with previous antiosteoporotic treatment, obese women $\left(\mathrm{BMI}=30.0 \mathrm{~kg} / \mathrm{m}^{2}\right.$ and above), women with a significant abuse (alcoholism, nicotinism, caffeinism), individuals with late-onset or premature menopause, and women with serious disturbances in the menstrual cycle. Clinical characteristics and parameters of the study population are shown in Table 1. The proportion of subjects with diagnosed osteoporosis accounted for $60.1 \%(N=206)$ of all women.

The studied women came from a Slovak southern region and, from a historical point of view, they could be 
Table 1 General characteristics of the studied groups of women

\begin{tabular}{|c|c|c|c|}
\hline Variable & $\begin{array}{l}\text { Total } \\
N=343\end{array}$ & $\begin{array}{l}\text { HT study } \\
N=76\end{array}$ & $\begin{array}{l}\text { Raloxifene study } \\
N=64\end{array}$ \\
\hline Age (years) & $62.40 \pm 0.46$ & $63.22 \pm 1.00$ & $65.30 \pm 0.98$ \\
\hline Body mass index (BMI) & $27.60 \pm 0.08$ & $27.30 \pm 0.18$ & $27.64 \pm 0.17$ \\
\hline BMD-FN (T-score) & $-1.79 \pm 0.03$ & $-2.13 \pm 0.04$ & $-2.16 \pm 0.06$ \\
\hline BMD-FN $\left(\mathrm{g} / \mathrm{cm}^{2}\right)$ & $0.65 \pm 0.01$ & $0.60 \pm 0.01$ & $0.60 \pm 0.01$ \\
\hline BMD-LS (T-score) & $-2.37 \pm 0.04$ & $-2.87 \pm 0.04$ & $-2.95 \pm 0.05$ \\
\hline BMD-LS $\left(\mathrm{g} / \mathrm{cm}^{2}\right)$ & $0.73 \pm 0.01$ & $0.68 \pm 0.01$ & $0.67 \pm 0.01$ \\
\hline Bone isoenzyme of alkaline phosphatase ( $\mu$ kat/l) & $0.56 \pm 0.04$ & $1.17 \pm 0.11$ & $0.68 \pm 0.08$ \\
\hline Osteocalcin $(\mu \mathrm{g} / \mathrm{l})$ & $3.85 \pm 0.05$ & $3.92 \pm 0.11$ & $4.25 \pm 0.13$ \\
\hline BetaCrosslaps (ng/l) & $709.65 \pm 13.57$ & $795.23 \pm 24.21$ & $876.86 \pm 28.06$ \\
\hline Serum calcium (mmol/l) & $2.40 \pm 0.01$ & $2.39 \pm 0.02$ & $2.46 \pm 0.03$ \\
\hline Serum phosphate $(\mathrm{mmol} / \mathrm{l})$ & $1.20 \pm 0.01$ & $1.19 \pm 0.02$ & $1.23 \pm 0.03$ \\
\hline
\end{tabular}

Data are presented as Mean \pm SE (SE - standard error of the mean)

$B M D$ bone mineral density, $H T$ hormone therapy (17ß estradiol/progesterone)

considered as descendants of a mixed Hungarian-Slavic population. This territory has been an important Hungarian-Slavic contact zone for more than thousand years [24] and it has homogeneously merged the overlapping populations with a different cultural, linguistic and geographic origin.

\section{Clinical data acquisition}

Personal and family history, age and life style habits were examined using a questionnaire (Additional file 1) that was completed by the subjects and reviewed by the qualified physician. BMI was calculated as weight in kilograms divided by height in meters squared. A prevalence (presence or absence) of total, femoral, radial, and spinal fragility fractures (also included compression fractures) in a period of last 5 years was diagnosed by clinical evaluation and using $\mathrm{X}$-rays radiographs. A detailed personal history was considered to avoid counting traumatic fractures. BMD expressed by $\mathrm{T}$-score and $\mathrm{g} / \mathrm{cm}^{2}$ of femoral (BMD-FN) and lumbar spine vertebrae (BMD-LS) was measured at the femoral neck and at the lumbar spine (L2-L4) by dual energy X-ray absorptiometry (HOLOGIC Discovery DXA system). All women were tested with the same densitometer. Biochemical markers of bone remodeling included osteoformation and osteoresorption markers - bone isoenzyme of alkaline phosphatase (ALP; $\mu \mathrm{kat} / \mathrm{l})$, serum osteocalcin (OC; $\mu \mathrm{g} / \mathrm{l})$, serum beta CrossLaps (CTx; ng/l). The ALP was determined by immunoenzymatic assay (Beckman Coulter Access Ostase assay, Beckman Coulter), the OC and CTx were measured by electrochemiluminescence immunoassay with cobas e411 (Roche Diagnostics) within a diagnostic screening. Concentrations of serum calcium ( $\mathrm{mmol} / \mathrm{l})$ and phosphate $(\mathrm{mmol} / \mathrm{l})$ were analysed by photometric assay with cobas c311 (Roche Diagnostics). All measurements were performed by accredited clinical laboratories in Nitra (Slovakia).

\section{Genetic analysis of the ESR1 gene}

Genomic DNA was extracted from EDTA blood samples using the blood isolation kit (SiMax ${ }^{\mathrm{ma}}$ Genomic DNA Extraction Kit, China). DNA was amplified by PCR using primers according to Kobayashi et al. [11]. PCR was performed with the following steps: $95{ }^{\circ} \mathrm{C}$ for $5 \mathrm{~min}$ and then $94{ }^{\circ} \mathrm{C}$ for $30 \mathrm{~s}, 60{ }^{\circ} \mathrm{C}$ for $30 \mathrm{~s}$, and $72{ }^{\circ} \mathrm{C}$ for $1 \mathrm{~min}$. The PCR consisted of 35 cycles and it was completed by a final extension cycle at $72{ }^{\circ} \mathrm{C}$ for $7 \mathrm{~min}$. The PCR product was a 1.3-kb long fragment including a part of intron 1 and exon 2 of the ESR 1 gene. After amplification, the PCR product was digested with $\mathrm{XbaI}$ and PvuII restriction endonucleases (Invitrogen) separately at $37{ }^{\circ} \mathrm{C}$ overnight and separated by electrophoresis in $2.0 \%$ agarose gel containing ethidium bromide. The gels were documented by DNR Bio-Imaging Systems (MiniBIS Pro, Israel). The " $G$ " and " $C$ " alleles indicate the absence of XbaI and PvuII restrictrion site, respectively, the " $\mathrm{A}$ " and " $\mathrm{T}$ " alleles indicate a presence of these restriction sites (Fig. 1).

\section{Pharmacogenetic study}

Data from osteoporotic women, who received regular anti-osteoporotic therapy during 48 months, were analysed (Table 1). BMDs (BMD-FN and BMD-LS) were measured before and after the treatment period. The therapy types included application of hormone therapy (HT) of $17 ß$ estradiol in combination with progesterone (1 $\mathrm{mg} /$ day for both; $N=76$ ) or SERMs/raloxifene (60 mg/day; $N=64)$. During a treatment, all women received a supplementation of calcium $(1000 \mathrm{mg} /$ day $)$ and vitamin D (800 IU/day).

\section{Statistical analysis}

The data were summarized as Mean \pm SE (Standard Error of the Mean) for quantitative variables and as 


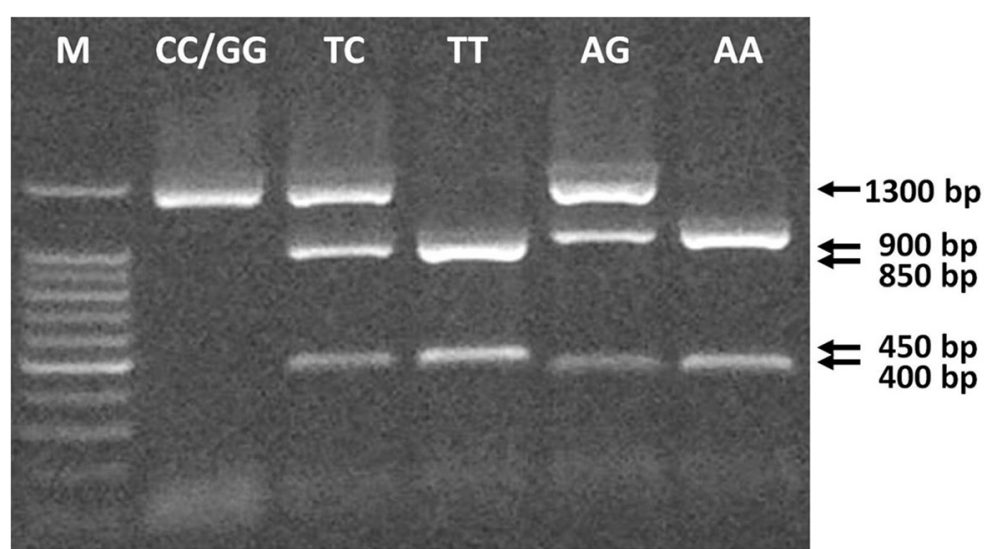

Fig. 1 Representative results of ESR1 genotypes detection. Lane M - 100 bp ladder; lane CC/GG - amplified ESR1 gene (1300 bp) and CC or GG genotypes; the other lanes represent combinations of DNA fragments related to the rest ESR1 genotypes

frequencies for qualitative variables. Genotype distribution was tested for Hardy-Weinberg equilibrium using the chi-square test. The differences of quantitative variables among the genotypes were analysed in quantitative design by covariance analysis (General Linear Model procedure, GLM) after correction of the measurements for age and BMI. A dominant genetic model (TT vs. TC + CC for rs2234693; AA vs. AG + GG for rs9340799) was chosen according to calculations by SNPStats (Institut Català d'Oncologia). Possible interactions (significance interval) were tested using Johnson-Neyman procedure [25]. For evaluation of fracture prevalence Binary Logistic Regression with the genotype, age and BMI as covariates was used. The effect of genotypes on BMD change during a treatment was assessed by variance analysis for repeated measurements using GLM, where the evaluated BMD before and after treatment represented a repeat dependent variable and the individual genotypes were fixed effects. The BMD improvement within a genotype was tested by the same procedure but without between subject factors. Corrections for multiple testing of genotype effects were performed by Bonferroni correction. Statistical analysis was realized using SPSS software version 17.0 (SPSS Inc.; Chicago, IL, USA). The same software package was used to calculate the observed power of the association and pharmacogenetic studies. According to the relatively small sample size, the ideal power analysis parameters for our study were expected at $80 \%$ for the observed power with small to medium effect size. The $p$-value less than 0.05 was considered to be statistically significant.

\section{Results}

In our studied group we found the highest frequencies of heterozygous genotypes for both polymorphisms (Table 2). The distribution of genotypes agreed with that expected according to the Hardy-Weinberg equilibrium.
In addition, rs2234693 and rs9340799 polymorphisms in the ESR1 gene were in linkage disequilibrium $\left(x^{2}=363.56\right.$; $P<0.001)$. The frequencies of the haplotypes counted $0.52,0.37,0.10$, and 0.01 for TA, CG, CA, and TG haplotypes, respectively.

Associations of rs9340799 and rs2234693 genotypes with the osteoporosis-related characteristics are presented in Table 3. The results of statistical analysis for rs9340799 polymorphism showed that femoral and spinal BMD were significantly higher in women with the AA genotype in comparison with AG + GG genotypes $(P<0.05)$. No statistically significant difference between the rs 9340799 genotypes was observed for other analysed traits (ALP, OC, CTx, Ca, P). Moreover, no association of rs2234693 genotype with BMD, biochemical markers of bone turnover and other serum parameters was found. A haplotype analysis revealed non-significant effects of TA and CG haplotypes on any of the analysed trait.

None of the polymorphisms of the ESR1 genotypes had an effect on fracture prevalence (Table 4). Femoral fractures were not included in the analysis because of a small number of femoral fracture carriers $(N=4)$.

The findings from the pharmacogenetic analysis showed that both evaluated treatment types had a significant effect on positive BMD change after 48 months of treatment (Table 5; Fig. 2). Within HT, an increase in T-score of $0.347 \pm 0.043$ and $0.687 \pm 0.057$ was found for BMD-FN and BMD-LS, respectively. Raloxifene increased the T-score by $0.242 \pm 0.070$ and $0.463 \pm 0.063$ in BMD-FN and BMD-LS, respectively. The treatment efficiency of the therapies ranged from +5.2 to $+11.3 \%$ of BMD increase. However, when considering the effects of the ESR1 gene, significant differences in treatment efficiency also between ESR1 genotypes were revealed (Tables 6, 7; Fig. 2). Significant changes were found in femoral neck, as well as in lumbar spine BMD. Among HT treated women, the subjects with GG genotype of rs9340799 had significantly 
Table 2 Distribution of ESR1 genotypes and alelles

\begin{tabular}{llllll}
\hline Polymorphism & Genotype & Number & Genotype frequency (\%) & HWE $P$ value & Alelle frequency \\
\hline rs9340799 & GG & 52 & 15.2 & $X 2=0.209$ & G $=0.38$ \\
& AG & 157 & 45.8 & & \\
& AA & 134 & 39.0 & & \\
rs2234693 & CC & 73 & 21.3 & $X 2=0.188$ & $C=0.47$ \\
& CT & 175 & 51.0 & & $T=0.53$ \\
& TT & 95 & 27.7 & & \\
\hline
\end{tabular}

HWE Hardy-Weinberg equilibrium (the chi-square test value)

better response to HT than those with AA genotype in both, BMD-FN $(P<0.05)$ and BMD-LS $(P<0.01)$. In these cases, the T-scores were different by $0.262 \pm 0.103$ and $0.345 \pm 0.100$ at BMD-FN and BMD-LS, respectively. Moreover in BMD-LS, the women with AA genotype responded poorly to the therapy when compared also with AG genotype (-0.221 \pm 0.077 of T-score; $P<0.05)$. Within the rs2234693 genotypes, individuals with $\mathrm{CC}(+0.354 \pm 0.094$ of T-score; $P \leq 0.001)$ and TC $(+0.215 \pm 0.080$ of T-score; $P<0.05)$ genotypes had better response to HT in BMD-LS in comparison with TT genotype carriers. Despite these differences, all genotypes (except for TT in BMD-FN) showed significant increase in BMD during HT treatment, counting from +3.4 to $+17.4 \%$.

The effect of the ESR1 gene on raloxifene therapy was reported only in relation to BMD-LS. Subjects with AA genotype had significantly worse response to raloxifene, counting $-0.299 \pm 0.113$ of $\mathrm{T}$-score $(\mathrm{P}<0.05)$, when compared with AG genotype. Finally, patients with TT genotype showed $0.394 \pm 0.110$ and $0.461 \pm 0.145$ lower T-score in BMD-LS $(\mathrm{P}<0.01)$ than those with the TC and CC genotypes, respectively. No changes were detected in the femoral neck BMD in relation to the raloxifene therapy.

Table 3 Associations of the rs9340799 and rs2234693 genotypes with osteoporosis-related traits

\begin{tabular}{|c|c|c|c|c|c|}
\hline \multirow[t]{2}{*}{ Parameter } & \multicolumn{2}{|c|}{ rs9340799:A > G genotypes } & \multirow[t]{2}{*}{ Sig. ( $P$ value) } & \multirow[t]{2}{*}{ Sig. Cov. } & \multirow[t]{2}{*}{ BMD difference } \\
\hline & $\begin{array}{l}\mathrm{AA} \\
N=134\end{array}$ & $\begin{array}{l}A G+G G \\
N=209\end{array}$ & & & \\
\hline BMD-FN (T-score) & $-1.716 \pm 0.044$ & $-1.837 \pm 0.035$ & 0.035 & A & $0.120 \pm 0.570$ \\
\hline BMD-FN $\left(\mathrm{g} / \mathrm{cm}^{2}\right)$ & $0.587 \pm 0.07$ & $0.566 \pm 0.06$ & 0.035 & A & $0.020 \pm 0.010$ \\
\hline BMD-LS (T-score) & $-2.262 \pm 0.062$ & $-2.432 \pm 0.049$ & 0.033 & $A, B$ & $0.170 \pm 0.079$ \\
\hline BMD-LS $\left(\mathrm{g} / \mathrm{cm}^{2}\right)$ & $0.741 \pm 0.07$ & $0.723 \pm 0.05$ & 0.033 & $A, B$ & $0.018 \pm 0.008$ \\
\hline ALP & $0.493 \pm 0.057$ & $0.588 \pm 0.046$ & NS & $A, B$ & \\
\hline OC & $3.833 \pm 0.086$ & $3.853 \pm 0.069$ & NS & A & \\
\hline$C T x$ & $691.442 \pm 21.246$ & $721.324 \pm 16.992$ & NS & A & \\
\hline sCa & $2.400 \pm 0.017$ & $2.399 \pm 0.014$ & NS & A & \\
\hline$s P$ & $1.191 \pm 0.015$ & $1.206 \pm 0.012$ & NS & B & \\
\hline \multirow[t]{2}{*}{ Parameter } & \multicolumn{2}{|c|}{ rs2234693:T > C genotypes } & Sig. (P value) & Sig. Cov. & BMD difference \\
\hline & $\begin{array}{l}T \\
N=95\end{array}$ & $\begin{array}{l}\mathrm{TC}+\mathrm{CC} \\
N=248\end{array}$ & & & \\
\hline BMD-FN (T-score) & $-1.714 \pm 0.053$ & $-1.818 \pm 0.032$ & NS & A & \\
\hline BMD-FN $\left(\mathrm{g} / \mathrm{cm}^{2}\right)$ & $0.585 \pm 0.09$ & $0.570 \pm 0.05$ & NS & A & \\
\hline BMD-LS (T-score) & $-2.277 \pm 0.073$ & $-2.400 \pm 0.045$ & NS & $A, B$ & \\
\hline BMD-LS $\left(\mathrm{g} / \mathrm{cm}^{2}\right)$ & $0.739 \pm 0.08$ & $0.726 \pm 0.05$ & NS & $A, B$ & \\
\hline ALP & $0.582 \pm 0.068$ & $0.547 \pm 0.042$ & NS & $A, B$ & \\
\hline OC & $3.926 \pm 0.102$ & $3.814 \pm 0.063$ & NS & A & \\
\hline$C T x$ & $696.002 \pm 25.214$ & $714.878 \pm 15.592$ & NS & A & \\
\hline sCa & $2.394 \pm 0.020$ & $2.401 \pm 0.013$ & NS & A & \\
\hline$s P$ & $1.170 \pm 0.018$ & $1.208 \pm 0.011$ & NS & & \\
\hline
\end{tabular}


Table 4 The effects of the rs9340799 and rs2234693 genotypes on fracture prevalence

\begin{tabular}{|c|c|c|c|c|c|c|}
\hline Fracture location & Genotypes & Presence of fractures & Absence of fractures & $P$ value & OR & $95 \% \mathrm{Cl}$ \\
\hline \multicolumn{7}{|c|}{ rs9340799:A > G genotypes } \\
\hline \multirow[t]{3}{*}{ Spinal } & GG & 12 & 40 & 0.744 & 0.869 & $0.373-2.024$ \\
\hline & $A G$ & 43 & 114 & 0.464 & 0.764 & $0.437-1.458$ \\
\hline & $\mathrm{AA}$ & 36 & 98 & & & \\
\hline \multirow[t]{3}{*}{ Radial } & GG & 8 & 44 & 0.501 & 0.722 & $0.279-1.868$ \\
\hline & $A G$ & 27 & 130 & 0.371 & 0.735 & $0.375-1.442$ \\
\hline & $\mathrm{AA}$ & 21 & 113 & & & \\
\hline \multirow[t]{3}{*}{ Total } & GG & 13 & 39 & 0.913 & 1.046 & $0.469-2.330$ \\
\hline & $A G$ & 48 & 109 & 0.632 & 0.871 & $0.495-1.533$ \\
\hline & $\mathrm{AA}$ & 42 & 92 & & & \\
\hline \multicolumn{7}{|c|}{ rs2234693:T > C genotypes } \\
\hline \multirow[t]{3}{*}{ Spinal } & CC & 17 & 56 & 0.861 & 0.930 & $0.414-2.092$ \\
\hline & $\mathrm{TC}$ & 48 & 127 & 0.759 & 0.903 & $0.472-1.729$ \\
\hline & $\pi$ & 26 & 69 & & & \\
\hline \multirow[t]{3}{*}{ Radial } & CC & 10 & 63 & 0.856 & 0.918 & $0.363-2.322$ \\
\hline & $\mathrm{TC}$ & 31 & 144 & 0.501 & 0.779 & $0.377-1.610$ \\
\hline & $\pi$ & 15 & 80 & & & \\
\hline \multirow[t]{3}{*}{ Total } & CC & 18 & 55 & 0.858 & 1.073 & $0.497-2.315$ \\
\hline & $\mathrm{TC}$ & 56 & 119 & 0.583 & 0.843 & $0.458-1.552$ \\
\hline & $\pi$ & 29 & 66 & & & \\
\hline
\end{tabular}

The total number values count a presence of any fracture in an individual, $O R$ - the odds ratio, $\mathrm{Cl}$ - confidence interval, AA and $\Pi \mathrm{T}$ genotypes were set as baseline categories in a regression model; femoral fractures were not evaluated

\section{Discussion}

At older ages, osteoporosis may be the cause of diminished life quality, decreased functional independence, increased morbidity and, even sometimes, mortality. Genetic research helps to reveal responsible genetic factors, which can expand our possibilities in the treatment of the disease or an identification of individuals at risk.

Our results point to similar genetic variability in rs2234693 and rs9340799 polymorphisms as in other Caucasian populations $[9,19,26,27]$. Differences in genotype distribution of both polymorphisms can be found between
Caucasian and other populations. Data from Asian populations [11, 28-30] showed differential range of allele and genotype frequency. The rs 2234693 genotype distribution moves in the range of $14.0-19.3 \%, 43.6-54.8 \%$, and $29.4-$ $39.1 \%$ for CC, TC, and TT genotypes, respectively. The rs9340799 genotype distribution counts 3.5-7.0\%, 27.4$35.0 \%$, and $58.6-67.2 \%$ for GG, AG, and AA genotype, respectively.

In our study, an association between rs9340799 polymorphism of the ESR1 gene and BMD was found. The AA genotype individuals had a significantly higher BMD

Table 5 The effect of a treatment type on BMD change

\begin{tabular}{llllll}
\hline Treatment type & Skeletal site & BMD before treatment & BMD after treatment & BMD difference after treatment & Sig. $(P$ value $)$ \\
\hline HT & FN T-score & $-2.132 \pm 0.044$ & $-1.784 \pm 0.041$ & $0.347 \pm 0.043$ & 0.001 \\
& FN BMD & $0.603 \pm 0.06$ & $0.649 \pm 0.05$ & $0.046 \pm 0.05(+7.3 \%)$ & 0.001 \\
raloxifene & LS T-score & $-2.871 \pm 0.044$ & $-2.184 \pm 0.048$ & $0.687 \pm 0.057$ & 0.001 \\
& LS BMD & $0.674 \pm 0.005$ & $0.755 \pm 0.005$ & $0.081 \pm 0.006(+11.3 \%)$ & 0.001 \\
& FN T-score & $-2.155 \pm 0.059$ & $-1.913 \pm 0.078$ & $0.242 \pm 0.070$ & 0.002 \\
& FN BMD & $0.597 \pm 0.008$ & $0.635 \pm 0.010$ & $0.038 \pm 0.009(+5.2 \%)$ & 0.002 \\
& LS T-Score & $-2.947 \pm 0.054$ & $-2.484 \pm 0.070$ & $0.463 \pm 0.063$ & 0.001 \\
\hline
\end{tabular}

BMD of femoral neck (FN) and lumbal spine (LS) is expressed as Estimated Marginal Mean \pm SE (SE - standard error of the mean) of T-score (FN and LS T-score) and $\mathrm{g} / \mathrm{cm}^{2}$ (FN and LS BMD); HT - hormone therapy (17ß estradiol/progesterone); Sig. - significance of BMD difference after treatment, $\mathrm{P}$ values determine significant differences $(P<0.05)$ 


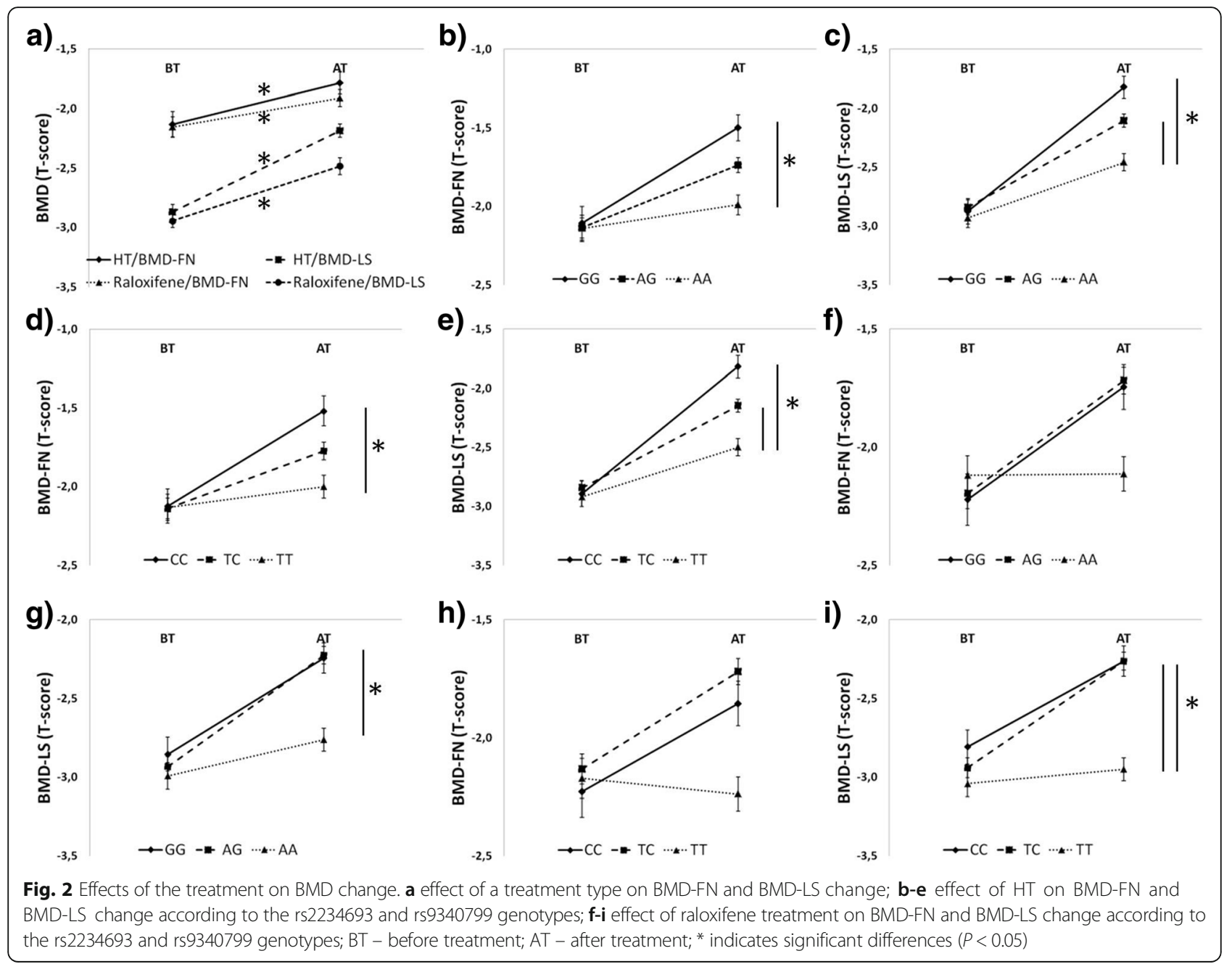

values compared to AG + GG genotypes. Previous association studies, involving different populations, have produced inconsistent results. In most studies of Caucasian populations, significant associations of rs2234693 and rs9340799 polymorphisms and BMD have not been recorded [31, 32]. Higher BMD-FN was revealed in women from the United States, who were homozygous for $C$ and $\mathrm{G}$ alleles of the ESR1 gene [13]. Van Meurs et al. [10] investigated the impact of rs2234693/rs9340799 haplotypes on BMD in a large population sample of white postmenopausal women, and found a significant association of the TA haplotype with a decreased BMD-LS, whereas the CG haplotype was associated with an increased BMD-LS; no association was found with BMD-FN. In addition, Albagha et al. [26] analysed white women from the United Kingdom, and found that only the CA haplotype was associated with lower values of BMD. Inconsistent results of association studies can be observable also in Asian populations [28-30]. A meta-analysis of 30 studies published by Ioannidis et al. [33] showed a positive effect of GG genotype on BMD and fracture risk, whereas rs 2234693 polymorphism was not associated with these traits. In a recent review and meta-analysis of Zhu et al. [34] the authors found significant associations of ESR1 polymorphisms with BMD in Caucasian women. The GG and AG genotypes were associated with increased FN BMD and FN Z value, respectively. These genotypes also had a higher LS $Z$ value in comparison with AA genotype. CC genotype was associated with a low LS $Z$ value, TC genotype in osteoporotic women was significantly correlated with low FN Z value. The discrepancies between different studies and populations can be explained by ethnic differences or higher variability in studied samples (peri-, pre-, post-menopausal women, multiple pregnancies, different sample size). Interactions between ESR1 gene and other genetic polymorphisms should also be considered [29, 35].

We did not find any association between ESR1 genotypes and a presence of fractures. Within a meta-analysis of Tang et al. [36], rs2234693/T allele was strongly identified as a significant risk factor for hip fracture among Caucasian populations, but not in Asian ones. However, in addition to $\mathrm{BMD}$, genetic factors may contribute to 
Table 6 BMD changes after hormone therapy in relation to the rs9340799 and rs2234693 genotypes

\begin{tabular}{|c|c|c|c|c|c|c|}
\hline Genotypes & Skeletal site & BMD before treatment & BMD after treatment & BMD difference after treatment & GLM Sig. ( $P$ value) & PC Sig. ( $P$ value) \\
\hline \multicolumn{7}{|c|}{ rs9340799:A > G genotypes } \\
\hline \multirow[t]{2}{*}{ GG } & FN T-score & $-2.108 \pm 0.106$ & $-1.500 \pm 0.082$ & $0.608 \pm 0.090$ & 0.001 & \\
\hline & FN BMD & $0.605 \pm 0.013$ & $0.678 \pm 0.010$ & $0.073 \pm 0.011(+12.6 \%)$ & 0.001 & \\
\hline \multirow[t]{2}{*}{$A G$} & FN T-score & $-2.138 \pm 0.063$ & $-1.738 \pm 0.049$ & $0.400 \pm 0.061$ & 0.001 & \\
\hline & FN BMD & $0.601 \pm 0.008$ & $0.649 \pm 0.006$ & $0.048 \pm 0.007(+8.4 \%)$ & 0.001 & \\
\hline \multirow[t]{2}{*}{ AA } & FN T-score & $-2.141 \pm 0.082$ & $-1.991 \pm 0.063$ & $0.150 \pm 0.066$ & 0.035 & \\
\hline & FN BMD & $0.601 \pm 0.010$ & $0.619 \pm 0.008$ & $0.018 \pm 0.008(+3.4 \%)$ & 0.035 & \\
\hline \multirow[t]{2}{*}{ GG-AG } & FN T-score & & & $0.134 \pm 0.952$ & 0.042 for $F N$ & NS \\
\hline & FN BMD & & & $0.016 \pm 0.011$ & $\begin{array}{l}\text { T-score and } \\
\text { FN BMD }\end{array}$ & NS \\
\hline \multirow[t]{2}{*}{ GG-AA } & FN T-score & & & $0.262 \pm 0.103$ & & 0.035 \\
\hline & FN BMD & & & $0.031 \pm 0.012$ & & 0.035 \\
\hline \multirow[t]{2}{*}{ AG-AA } & FN T-score & & & $0.128 \pm 0.795$ & & NS \\
\hline & FN BMD & & & $0.015 \pm 0.010$ & & NS \\
\hline \multirow[t]{2}{*}{ GG } & LS T-score & $-2.877 \pm 0.109$ & $-1.823 \pm 0.094$ & $1.054 \pm 0.053$ & 0.001 & \\
\hline & LS BMD & $0.675 \pm 0.012$ & $0.788 \pm 0.010$ & $0.113 \pm 0.006(+16.9 \%)$ & 0.001 & \\
\hline \multirow[t]{2}{*}{$A G$} & LS T-score & $-2.843 \pm 0.064$ & $-2.105 \pm 0.056$ & $0.738 \pm 0.073$ & 0.001 & \\
\hline & LS BMD & $0.679 \pm 0.007$ & $0.758 \pm 0.006$ & $0.079 \pm 0.008(+11.9 \%)$ & 0.001 & \\
\hline \multirow[t]{2}{*}{ AA } & LS T-score & $-2.932 \pm 0.083$ & $-2.459 \pm 0.073$ & $0.473 \pm 0.125$ & 0.001 & \\
\hline & LS BMD & $0.669 \pm 0.009$ & $0.720 \pm 0.008$ & $0.051 \pm 0.013(+8.3 \%)$ & 0.001 & \\
\hline \multirow[t]{2}{*}{ GG-AG } & LS T-score & & & $0.124 \pm 0.092$ & 0.002 for $F N$ & NS \\
\hline & LS BMD & & & $0.013 \pm 0.010$ & $\begin{array}{l}\text { I-score and } \\
\text { FN BMD }\end{array}$ & NS \\
\hline \multirow[t]{2}{*}{ GG-AA } & LS T-score & & & $0.345 \pm 0.100$ & & 0.003 \\
\hline & LS BMD & & & $0.037 \pm 0.011$ & & 0.003 \\
\hline \multirow[t]{2}{*}{ AG-AA } & LS T-score & & & $0.221 \pm 0.077$ & & 0.014 \\
\hline & LS BMD & & & $0.024 \pm 0.008$ & & 0.014 \\
\hline \multicolumn{7}{|c|}{ rs2234693:T > C genotypes } \\
\hline \multirow[t]{2}{*}{ CC } & FN T-score & $-2.124 \pm 0.093$ & $-1.518 \pm 0.072$ & $0.606 \pm 0.081$ & 0.001 & \\
\hline & FN BMD & $0.603 \pm 0.011$ & $0.676 \pm 0.09$ & $0.073 \pm 0.010(+12.6 \%)$ & 0.001 & \\
\hline \multirow[t]{2}{*}{ TC } & FN T-score & $-2.139 \pm 0.064$ & $-1.772 \pm 0.049$ & $0.367 \pm 0.058$ & 0.001 & \\
\hline & FN BMD & $0.601 \pm 0.008$ & $0.645 \pm 0.006$ & $0.044 \pm 0.007(+7.7 \%)$ & 0.001 & \\
\hline \multirow[t]{2}{*}{$\pi$} & FN T-score & $-2.132 \pm 0.088$ & $-2.000 \pm 0.068$ & $0.132 \pm 0.077$ & NS & \\
\hline & FN BMD & $0.602 \pm 0.011$ & $0.618 \pm 0.008$ & $0.016 \pm 0.009(+3.0 \%)$ & NS & \\
\hline \multirow[t]{2}{*}{ CC-TC } & FN T-score & & & & NS for FN & \\
\hline & FN BMD & & & & $\begin{array}{l}\text { T-score and } \\
\text { FN BMD }\end{array}$ & \\
\hline \multirow[t]{2}{*}{ CC-TT } & FN T-score & & & & & \\
\hline & FN BMD & & & & & \\
\hline \multirow[t]{2}{*}{ TC-TT } & FN T-score & & & & & \\
\hline & FN BMD & & & & & \\
\hline \multirow[t]{2}{*}{ CC } & LS T-score & $-2.894 \pm 0.095$ & $-1.818 \pm 0.079$ & $1.077 \pm 0.067$ & 0.001 & \\
\hline & LS BMD & $0.673 \pm 0.010$ & $0.789 \pm 0.008$ & $0.115 \pm 0.007(+17.4 \%)$ & 0.001 & \\
\hline \multirow[t]{2}{*}{$\mathrm{TC}$} & LS T-score & $-2.844 \pm 0.065$ & $-2.147 \pm 0.054$ & $0.697 \pm 0.064$ & 0.001 & \\
\hline & LS BMD & $0.679 \pm 0.007$ & $0.753 \pm 0.006$ & $0.075 \pm 0.007(+11.2 \%)$ & 0.001 & \\
\hline \multirow[t]{2}{*}{$\pi$} & LS T-score & $-2.921 \pm 0.090$ & $-2.500 \pm 0.075$ & $0.421 \pm 0.146$ & 0.010 & \\
\hline & LS BMD & $0.670 \pm 0.010$ & $0.715 \pm 0.008$ & $0.045 \pm 0.016(+7.6 \%)$ & 0.010 & \\
\hline
\end{tabular}


Table 6 BMD changes after hormone therapy in relation to the rs9340799 and rs2234693 genotypes (Continued)

\begin{tabular}{|c|c|c|c|c|c|c|}
\hline Genotypes & Skeletal site & BMD before treatment & BMD after treatment & BMD difference after treatment & GLM Sig. ( $P$ value) & PC Sig. ( $P$ value) \\
\hline \multirow[t]{2}{*}{ CC-TC } & LS T-score & & & $0.140 \pm 0.083$ & \multirow{6}{*}{$\begin{array}{l}0.001 \text { for } F N \\
\text { T-score and } \\
\text { FN BMD }\end{array}$} & NS \\
\hline & LS BMD & & & $0.015 \pm 0.009$ & & NS \\
\hline \multirow[t]{2}{*}{ CC-TT } & LS T-score & & & $0.354 \pm 0.094$ & & 0.001 \\
\hline & LS BMD & & & $0.038 \pm 0.010$ & & 0.001 \\
\hline \multirow[t]{2}{*}{ TC-TT } & LS T-score & & & $0.215 \pm 0.080$ & & 0.026 \\
\hline & LS BMD & & & $0.023 \pm 0.009$ & & 0.026 \\
\hline
\end{tabular}

BMD of femoral neck (FN) and lumbal spine (LS) is expressed as Estimated Marginal Mean \pm SE (SE - standard error of the mean) of T-score (FN and LS T-score) and $\mathrm{g} / \mathrm{cm}^{2}$ (FN and LS BMD), GLM Sig. - significance of GLM, PC Sig. - significance of pairwise comparisons, NS - non-significant GLM/BMD differences, $P$ values determine significant BMD differences $(P<0.05)$

fracture risk through mechanisms other than bone mass. These factors can include various skeletal characteristics like bone size and shape, cortical porosity, trabecular microarchitecture, and osteocyte cell function that may not be well captured by BMD measurements alone [37]. Some studies point to the importance of bone microdamage accumulation in the initiation of bone resorption and remodeling [38]. It would be perspective to include these factors into analyses in relation to fractures. Moreover, BMD changes have a long-term character, while bone turnover markers can directly infer about processes in bone tissue (formation/resorption). In our study, no differences in bone turnover markers between ESR1 genotypes were observed. In recent years, large genome-wide association studies (GWAS) have brought new insights into the genetics of osteoporosis. Some of the studies replicated previously reported candidate genes (including the ESR1 gene) in association with BMD and fracture risk [3]. The largest meta-analysis [39] included 17 genome-wide association studies with individuals of European and East Asian ancestry and identified 56 loci (with 24 reported previously) associated with BMD variation and 14 loci associated with risk of fracture. Further studies should be directed towards polymorphisms that have shown significant results in genome-wide association studies to evaluate their effect in specific populations.

Pharmacogenetic research has a potential to allow efficacious treatments, with consequent better chances for the patient health and reduced economic loss [40]. In our study, the effect of rs2234693 and rs9340799 polymorphisms on antiosteoporotic treatment efficiency was revealed. Similar outcomes, where genotypes with $\mathrm{C}$ or $G$ alleles were associated with greater sensitivity to HT, have been documented in other studies. Salmen et al. [19] analysed Finnish postmenopausal women during 5-years of HT. They found that women with the TT genotype had a greater fracture risk in comparison with $C$ allele carriers. In study of Giguere et al. [41], women with combined VDR-bb/ESR1-CC genotype who received HT for more than 5 years, had a $21 \%$ greater ultrasound heel stiffness index $\mathrm{z}$ score (comparable with BMD scores) than those with the same genotype receiving HT for less than 5 years. The study included postmenopausal women of French-Canadian origin. Rapuri et al. [20] reported significantly higher BMD response to HT treatment in women with the CC genotype compared to TT genotype. Similar findings with a positive effect of the $\mathrm{C}$ allele on vertebral BMD were found in the study by Ongphiphadhanakul et al. [21]. Subjects consisted of Thai post-menopausal women and the effect was not found on femoral BMD. Greater increase in lumbar spine BMD was recorded in $\mathrm{CC}$ genotypes in postmenopausal Japanese women [12]. No differences in HT efficiency have also been demonstrated in other studies [42, 43].

SERMs have the ability to bind to the estrogen receptor and act as a receptor agonist or antagonist in a tissue-specific manner. Raloxifene (the estrogen receptor agonist in bone) was the first SERM approved for the prevention and treatment of postmenopausal osteoporosis [44]. According to our results, individuals with CC or TC genotypes of rs2234693 and AG genotype of rs9340799 better responded on raloxifene therapy with higher BMD-LS changes in comparison with homozygous TT or AA genotypes. Similarly, postmenopausal osteoporotic women with the $\mathrm{CC}$ or AA genotypes on chronic hemodialysis exhibited a better lumbar spine BMD response in a study by Heilberg et al. [45]. Higher increase in total hip BMD was also noticed in postmenopausal women with osteoporosis carrying CC or TC genotypes [46]. Positive efficacy of raloxifene on BMD was also monitored in relation to other genes [47, 48].

Focusing on the percent change in BMD, a very high treatment efficacy in our study is remarkable, reaching up to 11.3 and $7.7 \%$ for HT and raloxifene in LS site, respectively. A meta-analysis of Wells et al. [49] showed a BMD-LS gain of $8 \%$ using high-dose estrogen (equivalent to $0.9 \mathrm{mg}$ Premarin) during 2 years. The BMD-LS improvement after raloxifene therapy usually reaches around $2.5 \%$ after 2 years [50]. Several factors may contribute to the differences between studies. From the 
Table 7 BMD changes after raloxifene therapy in relation to the rs9340799 and rs2234693 genotypes

\begin{tabular}{|c|c|c|c|c|c|c|}
\hline Genotype & Skeletal site & BMD before treatment & BMD after treatment & BMD difference after treatment & GLM Sig. ( $P$ value) & PC Sig. ( $P$ value) \\
\hline \multirow[t]{2}{*}{ GG } & FN T-score & $-2.222 \pm 0.160$ & $-1.744 \pm 0.201$ & $0.478 \pm 0.105$ & 0.002 & \\
\hline & FN BMD & $0.591 \pm 0.019$ & $0.649 \pm 0.024$ & $0.057 \pm 0.013(+10.2 \%)$ & 0.002 & \\
\hline \multirow[t]{2}{*}{ AG } & FN T-score & $-2.196 \pm 0.100$ & $-1.717 \pm 0.126$ & $0.478 \pm 0.157$ & 0.006 & \\
\hline & FN BMD & $0.595 \pm 0.012$ & $0.652 \pm 0.015$ & $0.057 \pm 0.019(+9.9 \%)$ & 0.006 & \\
\hline \multirow[t]{2}{*}{ AA } & FN T-score & $-2.119 \pm 0.086$ & $-2.113 \pm 0.108$ & $0.006 \pm 0.058$ & NS & \\
\hline & FN BMD & $0.604 \pm 0.010$ & $0.604 \pm 0.013$ & $0.001 \pm 0.007(+0.46 \%)$ & NS & \\
\hline \multirow[t]{2}{*}{ GG-AG } & FN T-score & & & & NS for FN & \\
\hline & FN BMD & & & & $\begin{array}{l}\text { I-score and } \\
\text { FN BMD }\end{array}$ & \\
\hline \multirow[t]{2}{*}{ GG-AA } & FN T-score & & & & & \\
\hline & FN BMD & & & & & \\
\hline \multirow[t]{2}{*}{ AG-AA } & FN T-score & & & & & \\
\hline & FN BMD & & & & & \\
\hline \multirow[t]{2}{*}{ GG } & LS T-score & $-2.856 \pm 0.145$ & $-2.244 \pm 0.167$ & $0.611 \pm 0.082$ & 0.001 & \\
\hline & LS BMD & $0.677 \pm 0.016$ & $0.743 \pm 0.018$ & $0.065 \pm 0.009(+9.7 \%)$ & 0.001 & \\
\hline \multirow[t]{2}{*}{ AG } & LS T-score & $-2.935 \pm 0.091$ & $-2.226 \pm 0.105$ & $0.709 \pm 0.087$ & 0.001 & \\
\hline & LS BMD & $0.669 \pm 0.010$ & $0.745 \pm 0.011$ & $0.076 \pm 0.009(+11.5 \%)$ & 0.001 & \\
\hline \multirow[t]{2}{*}{ AA } & LS T-score & $-2.994 \pm 0.078$ & $-2.765 \pm 0.090$ & $0.229 \pm 0.094$ & 0.021 & \\
\hline & LS BMD & $0.663 \pm 0.008$ & $0.687 \pm 0.010$ & $0.025 \pm 0.010(+4.1 \%)$ & 0.021 & \\
\hline \multirow[t]{2}{*}{ GG-AG } & LS T-score & & & $0.030 \pm 0.161$ & \multirow{6}{*}{$\begin{array}{l}0.016 \text { for FN } \\
\text { T-score and } \\
\text { FN BMD }\end{array}$} & NS \\
\hline & LS BMD & & & $0.003 \pm 0.017$ & & NS \\
\hline \multirow[t]{2}{*}{ GG-AA } & LS T-score & & & $0.329 \pm 0.155$ & & NS \\
\hline & LS BMD & & & $0.035 \pm 0.017$ & & NS \\
\hline \multirow[t]{2}{*}{ AG-AA } & LS T-score & & & $0.299 \pm 0.113$ & & 0.028 \\
\hline & LS BMD & & & $0.032 \pm 0.012$ & & 0.028 \\
\hline \multirow[t]{2}{*}{ CC } & FN T-score & $-2.227 \pm 0.145$ & $-1.855 \pm 0.177$ & $0.373 \pm 0.093$ & 0.002 & \\
\hline & FN BMD & $0.591 \pm 0.017$ & $0.635 \pm 0.021$ & $0.045 \pm 0.092(+7.8 \%)$ & 0.002 & \\
\hline \multirow[t]{2}{*}{ TC } & FN T-score & $-2.132 \pm 0.086$ & $-1.719 \pm 0.106$ & $0.413 \pm 0.124$ & 0.002 & \\
\hline & FN BMD & $0.602 \pm 0.010$ & $0.652 \pm 0.013$ & $0.050 \pm 0.015(+8.6 \%)$ & 0.002 & \\
\hline \multirow[t]{2}{*}{$\Pi$} & FN T-score & $-2.171 \pm 0.105$ & $-2.238 \pm 0.128$ & $0.067 \pm 0.060$ & NS & \\
\hline & FN BMD & $0.597 \pm 0.013$ & $0.589 \pm 0.015$ & $-0.008 \pm 0.007(-1.0 \%)$ & NS & \\
\hline \multirow[t]{2}{*}{ CC-TC } & FN T-score & & & & NS for FN & \\
\hline & FN BMD & & & & $\begin{array}{l}\text { T-score and } \\
\text { FN BMD }\end{array}$ & \\
\hline \multirow[t]{2}{*}{ CC-TT } & FN T-score & & & & & \\
\hline & FN BMD & & & & & \\
\hline \multirow[t]{2}{*}{ TC-TT } & FN T-score & & & & & \\
\hline & FN BMD & & & & & \\
\hline \multirow[t]{2}{*}{ CC } & LS T-score & $-2.809 \pm 0.130$ & $-2.264 \pm 0.140$ & $0.546 \pm 0.092$ & 0.001 & 0.001 \\
\hline & LS BMD & $0.682 \pm 0.014$ & $0.741 \pm 0.015$ & $0.058 \pm 0.010(+8.6 \%)$ & 0.001 & 0.001 \\
\hline \multirow[t]{2}{*}{ TC } & LS T-score & $-2.942 \pm 0.077$ & $-2.265 \pm 0.084$ & $0.677 \pm 0.074$ & 0.001 & 0.001 \\
\hline & LS BMD & $0.668 \pm 0.008$ & $0.741 \pm 0.009$ & $0.073 \pm 0.008(+11.0 \%)$ & 0.001 & 0.001 \\
\hline \multirow[t]{2}{*}{$\pi$} & LS T-score & $-3.043 \pm 0.094$ & $-2.952 \pm 0.102$ & $0.091 \pm 0.114$ & NS & NS \\
\hline & LS BMD & $0.657 \pm 0.010$ & $0.667 \pm 0.011$ & $0.010 \pm 0.012(+2.0 \%)$ & NS & NS \\
\hline
\end{tabular}


Table 7 BMD changes after raloxifene therapy in relation to the rs9340799 and rs2234693 genotypes (Continued)

\begin{tabular}{|c|c|c|c|c|c|}
\hline Genotype & Skeletal site & BMD before treatment $\quad B M D$ after treatment & BMD difference after treatment & GLM Sig. ( $P$ value) & PC Sig. ( $P$ value $)$ \\
\hline \multirow[t]{2}{*}{$\overline{C C-T C}$} & LS T-score & & $0.067 \pm 0.137$ & \multirow{6}{*}{$\begin{array}{l}0.001 \text { for FN } \\
\text { T-score and } \\
\text { FN BMD }\end{array}$} & NS \\
\hline & LS BMD & & $0.007 \pm 0.015$ & & NS \\
\hline \multirow[t]{2}{*}{ CC-TT } & LS T-score & & $0.461 \pm 0.145$ & & 0.007 \\
\hline & LS BMD & & $0.049 \pm 0.016$ & & 0.007 \\
\hline \multirow[t]{2}{*}{$\mathrm{TC}-\mathrm{TT}$} & LS T-score & & $0.394 \pm 0.110$ & & 0.002 \\
\hline & LS BMD & & $0.042 \pm 0.012$ & & 0.002 \\
\hline
\end{tabular}

BMD of femoral neck (FN) and lumbal spine (LS) is expressed as Estimated Marginal Mean \pm SE (SE - standard error of the mean) of T-score (FN and LS T-score) and $\mathrm{g} / \mathrm{cm}^{2}$ (FN and LS BMD); GLM Sig. - significance of GLM, PC Sig. - significance of pairwise comparisons, NS - non-significant GLM/BMD differences, $P$ values determine significant BMD differences $(P<0.05)$

point of view of our study, we can consider especially limited sample size, differences from other studies in BMD baseline, population composition, or inclusion criteria (e.g. adequacy of calcium/vitamin D intake, previous anti-resorptive treatment). The effect of a therapy was also found to be a dose and time dependent.

Considering limitations of our study, the small sample size seems to be the most important. Despite the ability to calculate optimal sample size, the number of observations is often dependent on the existing economic and human resources or the time available for carrying out the study. The observed power for our study, where the model was significant, ranged from 69 to $73 \%$ and from 78 to $94 \%$ for association and pharmacogenetic analyses, respectively. Moreover, the revealed effects of the polymorphisms cannot be confirmed on the molecular level. The mechanisms by which the polymorphisms may influence bone mass are still not clear, since these polymorphisms lie in an intronic area of the gene. However, a study of Herrington et al. [51] showed that a functional binding site for the transcription factor B-myb is absent with the $\mathrm{T}$ allele, which, in turn, may reduce ESR1 transcription rates or produce a functionally different ESR1 isoform. It has also been demonstrated that the ESR1 gene expression can be regulated by epigenetic mechanisms [52]. Moreover, there is still the possibility that both polymorphisms are only linkage markers and the effect itself is caused by another, closely related region of the ESR1 gene. In any case, all the mechanisms may also be the cause of different impacts of individual polymorphisms on the analysed parameters. Other limitations can involve gene-gene and gene-environment interactions, or epigenetic factors which could influence the pharmacodynamics and pharmacokinetics of individual drug response [18]. Nevertheless, the pharmacogenetic research is promising, especially for osteoporosis, that require long-term treatments and where different therapy types exist to be alternatively chosen.

\section{Conclusion}

We found that rs9340799 polymorphism may contribute to decreased BMD in postmenopausal women from southern Slovakia, whereas rs2234693 polymorphism did not affect any of the analyzed parameters. The ESR1 gene was not significantly related to fracture prevalence. Our study also demonstrated the effect of both ESR1 gene polymorphisms on the effectiveness of HT (17ß estradiol/progesterone), as well as SERMs/raloxifene therapies with poorer response in patients with rs2234693/ TT and rs9340799/AA genotypes. The results can contribute to a more comprehensive insight to the genetics and pharmacogenetics of osteoporosis. The evaluation of effects of previously revealed candidate genes in specific populations may get closer to the practical use of results in predictive genetics and personalized medicine.

\section{Additional file}

Additional file 1: Anamnestic questionnaire for osteological examination. Questionnaire form for personal and family history, age, and life style habits data acquisition. (PDF $332 \mathrm{~kb}$ )

\begin{abstract}
Abbreviations
ALP: Bone isoenzyme of alkaline phosphatase; BMD: Bone mineral density; BMD-FN: Femoral neck bone mineral density; BMD-LS: Lumbar spine bone mineral density; BMI: Body mass index; BPs: Bisphosphonates; Cl: Confidence interval; CTx: Beta CrossLaps; ESR1: Estrogen receptor 1 gene; FN: Femoral neck; GLM: General linear model; GWAS: Genome-wide association studies; HT: Hormone therapy; HWE: Hardy-Weinberg equilibrium; LS: Lumbar spine; NS: Non-significant; OC: Osteocalcin; OR: The odds ratio; PC Sig.: Significance of pairwise comparisons; PCR: Polymerase chain reaction; sCa: serum calcium; SE: Standard error of the mean; SERMs: Selective estrogen receptor modulators; Sig. Cov.: Significance of covariates; Sig.: Significance; sP: serum phosphate; VDR: Vitamin D receptor gene
\end{abstract}

\section{Funding}

The study was supported by the projects VEGA 1/0505/18 and KEGA 031 UKF-4/2016.

\section{Availability of data and materials}

The clinical raw datasets supporting our findings will be available upon request from the authors. 


\section{Authors' contributions}

The conception and design of the work: RO, VM. Performed the experiments: $V M, M A, M L, R B$. The acquisition and interpretation of data: $R O, V M, D G, B G, M M$. Drafting the work or revising it critically for important intellectual content: $\mathrm{RO}$, $V M, M A, B G, M M$. Final approval of the version to be published: RO, VM, MA, $M L, R B, B G, D G, M M$. All authors read and approved the final manuscript.

\section{Ethics approval and consent to participate}

All procedures in our study were approved by the Ethical Committee of the Specialized Hospital of St. Svorad in Nitra (Slovakia). The acquisition of personal, clinical and treatment data, as well as genetic analysis were realized with written informed consent of the subjects. All therapies included in this study followed the clinical guidelines in health supplement from Public Health Authority of the Slovak Republic.

\section{Consent for publication}

Not applicable.

\section{Competing interests}

The authors declare that they have no competing interests.

\section{Publisher's Note}

Springer Nature remains neutral with regard to jurisdictional claims in published maps and institutional affiliations.

\section{Author details}

'Department of Botany and Genetics, Constantine the Philosopher University in Nitra, Nitra, Slovak Republic. Institute of Zoology and Anthropology, Georg-August University, Göttingen, Germany. ${ }^{3}$ Department of Zoology and Anthropology, Constantine the Philosopher University in Nitra, Nitra, Slovak Republic. ${ }^{4}$ Private Orthopedic Ambulance, Nitra, Slovak Republic.

Received: 17 April 2018 Accepted: 9 September 2018

Published online: 21 September 2018

\section{References}

1. Ralston SH, Uitterlinden AG. Genetics of osteoporosis. Endocr Rev. 2010; 31(5):629-62.

2. Ralston SH. Genetic determinants of susceptibility to osteoporosis. Curr Opin Pharmacol. 2003;3(3):286-90.

3. Duncan EL, Danoy P, Kemp JP, Leo PJ, McCloskey E, Nicholson GC, Eastell R, Prince RL, Eisman JA, Jones G, Sambrook PN, Reid IR, Dennison EM, Wark J, Richards JB, Uitterlinden AG, Spector TD, Esapa C, Cox RD, Brown SD, Thakker RV, Addison KA, Bradbury LA, Center JR, Cooper C, Cremin C, Estrada K, Felsenberg D, Glüer CC, Hadler J, Henry MJ, Hofman A, Kotowicz MA, Makovey J, Nguyen SC, Nguyen TV, Pasco JA, Pryce K, Reid DM, Rivadeneira F, Roux C, Stefansson K, Styrkarsdottir U, Thorleifsson G, Tichawangana R, Evans DM, Brown MA. Genome-wide association study using extreme truncate selection identifies novel genes affecting bone mineral density and fracture risk. PLoS Genet. 2011;7(4):e1001372. https://doi.org/10.1371/journal.pgen.1001372.

4. Wang C, Zhang Z, Zhang H, He JW, Gu JM, Hu WW, Hu YQ, Li M, Liu YJ, Fu WZ, Yue H, Ke YH, Zhang ZL. Susceptibility genes for osteoporotic fracture in postmenopausal Chinese women. J Bone Miner Res. 2012;27(12):2582-91.

5. Eastell R. Pathogenesis in postmenopausal osteoporosis. In: Murray JF \& Associate editors: Primer on the metabolic bone diseases and disorders of mineral metabolism. USA: American society for bone and mineral research; 6th. 2006. p. 259-262.

6. Gennari L, Merlotti D, De Paola V, Calabró A, Becherini L, Martini G, Nuti R. Estrogen receptor gene polymorphisms and the genetics of osteoporosis: a HuGE review. Am J Epidemiol. 2005;161(4):307-20.

7. Gennari L, De Paola V, Merlotti D, Martini G, Nuti R. Steroid hormone receptor gene polymorphisms and osteoporosis: a pharmacogenomic review. Expert Opin Pharmacother. 2007;8(5):537-53.

8. Rooney AM, Van der Meulen MCH. Mouse models to evaluate the role of estrogen receptor a in skeletal maintenance and adaptation. Ann N Y Acad Sci. 2017:1410(1):85-92.

9. Becherini L, Gennari L, Masi L, Mansani R, Massart F, Morreli A, Falchetti AA, Gonelii S, Fiorelli G, Tanini A. Evidence of a linkage disequilibrium between polymorhism in the human estrogene receptor alpha gene and their relationship to bone mass variation in postmenopausal Italian woman. Hum Mol Genet. 2000:9(13):2043-50.

10. Van Maeurs JB, Schui SC, Weel AE. Associations of 5' estrogen receptor alpha gene polymorphism with bone mineral density, vertebral bone area and fracture risk. Hum Mol Genet. 2003;12(14):1745-54.

11. Kobayashi N, Inoue S, Hosoi T, Ouchi Y, Shiraki M, Orimo H. Association of bone mineral density with polymorphism of the estrogen receptor gene. J Bone Miner Res. 1996;11(3):306-11.

12. Kobayashi N, Fujino T, Shirogane T, Furuta I, Kobamatsu Y, Yaegashi M, Sakuragi N, Fujimoto S. Estrogen receptor alpha polymorphism as a genetic marker for bone loss, vertebral fractures and susceptibility to estrogen. Maturitas. 2002;41(3):193-201.

13. Sowers TD, Jannausch ML, Liang W, Willing M. Estrogen receptor genotypes and their associations with the 10-years changes in bone mineral density and osteocalcin concentrations. J Clin Endocrin Metab. 2004:89(2):733-9.

14. Jeedigunta Y, Reddy PRB, Kolla VK, Munshi A, Anathapur V, Narasimilu $G$, Akka J. Association of estrogen receptor a gene polymorphisms with BMD and their affect on estradiol levels in pre- and postmenopusal woman in south Indian population from Andhra Pradesh. Clin Chim Acta. 2010;411(7-8):597-600.

15. Kurt O, Yilmaz-Aydogan H, Uyar M, Isbir T, Seyhan MF, Can A. Evaluation of ERa and VDR gene polymorphisms in relation to bone mineral density in Turkish postmenopausal women. Mol Biol Rep. 2012;39(6):6723-30.

16. Chen JS, Sambrook PN. Antiresorptive therapies for osteoporosis: a clinical overview. Nat Rev Endocrinol. 2012;8(2):81-91.

17. Pickar JH, Komm BS. Selective estrogen receptor modulators and the combination therapy conjugated estrogens/bazedoxifene: a review of effects on the breast. Post Reprod Health. 2015;21(3):112-21.

18. Marini F, Brandi ML. Pharmacogenetics of osteoporosis. Best Pract Res Clin Endocrinol Metab. 2014;28(6):783-93.

19. Salmen T, Heikkinen AM, Mahonen A, Kroger H, Komulainen M, Saarikoski S, Honkanen R, Maenpaa PH. Early postmenopausal bone loss is associated with Pvu II estrogen receptor gene polymorphism in Finnish woman: effect of hormone replacement therapy. J Bone Miner Res. 2000;15(2):315-21.

20. Rapuri P, Gallagher J, Knezetic J, Haynatzka V. Estrogen receptor alpha gene polymorphisms are associated with changes in bone remodeling markers and treatment response to estrogen. Maturitas. 2006;53(4):371-9.

21. Ongphiphadhanakul B, Chanprasertyothin S, Payatikul P, Tung SS, Piaseu N, Chailurkit L, Chansirikarn S, Puavilai G, Rajatanavin R. Oestrogen-receptoralpha gene polymorphism affects response in bone mineral density to oestrogen in post-menopausal women. Clin Endocrinol. 2000;52(5):581-5.

22. Pavone V, Testa G, Giardina SMC, Vescio A, Restivo DA, Sessa G. Pharmacological therapy of osteoporosis: a systematic current review of literature. Front Pharmacol. 2017:8:803.

23. Nguyen TV, Eisman JA. Pharmacogenomics of osteoporosis: opportunities and challenges. J Musculoskelet Neuronal Interact. 2006;6:62-72.

24. Csákyová V, Szécsényi-Nagy A, Csősz A, Nagy M, Fusek G, Langó P, Bauer M, Mende BG, Makovický P, Bauerová M. Maternal genetic composition of a medieval population from a Hungarian-Slavic contact zone in Central Europe. PLoS One. 2016;11(3):e0151206. https://doi.org/ 10.1371/journal.pone.0151206 eCollection 2016.

25. D'Alonzo KT. The Johnson-Neyman procedure as an alternative to ANCOVA. West J Nurs Res. 2004:26(7):804-12.

26. Albagha OM, McGuigan FE, Reid DM, Ralston SH. Estrogen receptor alpha gene plymorphism and bone mineral density: haplotype analysis in woman from the UnitedKingdom. J Bone Min Res. 2001;16(1):128-34.

27. Bustamante M, Nogués X, Enjuanes A, Elosua R, García-Giralt N, Pérez-Edo L, Cáceres E, Carreras R, Mellibovsky L, Balcells S, Díez-Pérez A, Grinberg D. COL1A1, ESR1, VDR and TGFB1 polymorphisms and haplotypes in relation to BMD in Spanish postmenopausal women. Osteoporos Int. 2007;18(2):235-43.

28. Matsushita H, Kurabayashi T, Tomita M, Tanaka K. Effects of vitamin D and estrogen receptor gene polymorphisms on the changes in lumbar bone mineral density with multiple pregnancies in Japanese women. Hum Reprod. 2004;19(1):59-64.

29. Nam HS, Shin MH, Kweon SS, Park KS, Sohn SJ, Rhee JA, Choi JS, Son MH. Association of estrogen alpha receptor gene polymorphism with bone mineral density in Korean women. J Bone Min Metab. 2005;23(1):84-5.

30. Dai X, Wang C, Dai J, Shi D, Xu Z, Chen D, Teng H, Jiang Q. Association of single nucleotide polymorphisms in estrogen receptor alpha gene with susceptibility to knee osteoarthritis: a case-control study in a Chinese Han population. Biomed Res Int. 2014;2014:151457. 
31. Bagger $Y Z$, Jorgensen $H L$, Heegard AM, Bayer L, Hansen L, Hassager C. No major effect of estrogen receptor gene polymorphisms on bone mineral density of bone loss in postmenopausal Danish women. Bone. 2000;26(2):111-6.

32. Tanriover MD, Tatar GB, Uluturk TD, Erden DD, Tanriover A, Kilicarlslan A, Oz SG, Yurter HE, Sozen T, Guven GS. Evaluation of the effects of vitamin $D$ receptor and estrogen receptor 1 gene polymorphisms on bone mineral density in postmenopausal women. Clin Rheumatol. 2010; 29(11):1285-93

33. loannidis JP, Stavrou I, Trikalinos TA, Zois C, Brandi ML, Gennari L, Albagha O, Ralston SH, Tsatsoulis A. ER-alpha genetics meta-analysis. Association of polymorphisms of the estrogen receptor alpha gene with bone mineral density and fracture risk in women: a meta-analysis. J Bone Miner Res. 2002 17(11):2048-60.

34. Zhu H, Jiang J, Wang Q, Zong J, Zhang L, Ma T, Xu Y, Zhang L. Associations between $E R a / \beta$ gene polymorphisms and osteoporosis susceptibility and bone mineral density in postmenopausal women: a systematic review and meta-analysis. BMC Endocr Disord. 2018;18(1):11.

35. Correa-Rodríguez M, Viatte S, Massey J, Schmidt-RioValle J, Rueda-Medina B, Orozco G. Analysis of SNP-SNP interactions and bone quantitative ultrasound parameter in early adulthood. BMC Med Genet. 2017;18(1):107.

36. Tang $L$, Cheng $G L, X u Z H$. Association between estrogen receptor a gene (ESR1) Pvull (C/T) and Xbal (a/G) polymorphisms and hip fracture risk: evidence from a meta-analysis. PLoS One. 2013;8(12):e82806. https://doi.org/ 10.1371/journal.pone.0082806.

37. Zmuda JM, Cauley JA, Ferrell RE, Nevitt MC, Feingold E, Ensrud K, Stone KL, Hochberg MC, Harris EL, Cummings SR. Familial resemblance in fall-related risk factors in older woman. Calcif Tissue Int. 2000:67:497.

38. Boyde A. The real response of bone to exercise. J Anat. 2003;203(2):173-89.

39. Estrada K, Styrkarsdottir U, Evangelou E, et al. Genome-wide meta-analysis identifies 56 bone mineral density loci and reveals 14 loci associated with risk of fracture. Nat Genet. 2012;44(5):491-501.

40. Massart F, Brandi ML. Genetics of the bone response to bisphosphonate treatments. Clin Cases Miner Bone Metab. 2009;6(1):50-4.

41. Giguère $Y$, Dodin S, Blanchet C, Morgan K, Rousseau F. The association between heel ultrasound and hormone replacement therapy is modulated by a two-locus vitamin D and estrogen receptor genotype. J Bone Miner Res. 2000;15(6):1076-84.

42. Silvestri $S$, Thomsen AB, Gozzini A, Bagger $Y$, Christiansen C, Brandi ML. Estrogen receptor $\alpha$ and $\beta$ polymorphisms: is there an association with bone mineral density, plasma lipids, and response to postmenopausal hormone therapy. Menopause. 2006;13(3):451-61.

43. Masi L, Ottanelli S, Berni R, Cacudi E, Giusti F, Marcucci G, Cavalli L, Fossi C, Marini F, Ciuffi S, Tanini A, Brandi ML. CYP19 and ESR1 gene polymorphisms response of the bone mineral density in post-menopausal women to hormonal replacement therapy. Clin Cases Miner Bone Metab. 2014;11(1):36-43.

44. Ettinger B, Black DM, Mitlak BH, Knickerbocker RK, Nickelsen T, Genant HK, Christiansen C, Delmas PD, Zanchetta JR, Stakkestad J, Gluer CC, Krueger K, Cohen FJ, Eckert S, Ensrud KE, Avioli LV, Lips P, Cummings SR. Reduction of vertebral fracture risk in postmenopausal women with osteoporosis treated with raloxifene: results from a 3-year randomized clinical trial. Multiple outcomes of raloxifene evaluation (MORE) investigators. JAMA. 1999;282(7):637-45.

45. Heilberg IP, Hernandez E, Alonzo E, Valera R, Ferreira LG, Gomes SA, BellorinFont $E$, Weisinger JR. Estrogen receptor (ER) gene polymorphism may predict the bone mineral density response to raloxifene in postmenopausal women on chronic hemodialysis. Ren Fail. 2005;27(2):155-61.

46. Zhang ZL, He JW, Qin YJ, Huang QR, Liu YJ, Hu YQ, Li M. Association of bone metabolism related genes polymorphisms with the effect of raloxifene hydrochloride on bone mineral density and bone turnover markers in postmenopausal women with osteoporosis. Zhonghua Yi Xue Yi Chuan Xue Za Zhi. 2006;23(2):129-33.

47. Palomba S, Numis FG, Mossetti G, Rendina D, Vuotto P, Russo T, Zullo F, Nappi C, Nunziata V. Raloxifene administration in post-menopausal women with osteoporosis: effect of different Bsml vitamin D receptor genotypes. Hum Reprod. 2003;18(1):192-8.

48. Mencej-Bedrač S, Zupan J, Mlakar SJ, Zavratnik A, Preželj J, Marc J. Raloxifene pharmacodynamics is influenced by genetic variants in the RANKL/RANKOPG system and in the Wnt signaling pathway. Drug Metabol Drug Interact. 2014; 29(2):111-4
49. Wells G, Tugwell P, Shea B, Guyatt G, Peterson J, Zytaruk N, Robinson V, Henry D, O'Connell D. Cranney a; osteoporosis methodology group and the osteoporosis research advisory group. Meta-analyses of therapies for postmenopausal osteoporosis. V. Meta-analysis of the efficacy of hormone replacement therapy in treating and preventing osteoporosis in postmenopausal women. Endocr Rev. 2002;23(4):529-39.

50. Delmas PD, Davis SR, Hensen J, Adami S, van Os S, Nijland EA. Effects of tibolone and raloxifene on bone mineral density in osteopenic postmenopausal women. Osteoporos Int. 2008;19(8):1153-60.

51. Herrington DM, Howard TD, Hawkins GA, Reboussin DM, Xu J, Zheng SL, Brosnihan KB, Meyers DA, Bleecker ER. Estrogen receptor polymorphisms and effects of estrogen replacement on $\mathrm{HDL}$ cholesterol in women with coronary disease. N Engl J Med. 2002;346(13):967-74.

52. Lau KM, LaSpina M, Long J, Ho SM. Expression of estrogen receptor (ER)-alpha and ER-beta in normal and malignant prostatic epithelial cells: regulation by methylation and involvement in growth regulation. Cancer Res. 2000;60(12):3175-82.
Ready to submit your research? Choose BMC and benefit from:

- fast, convenient online submission

- thorough peer review by experienced researchers in your field

- rapid publication on acceptance

- support for research data, including large and complex data types

- gold Open Access which fosters wider collaboration and increased citations

- maximum visibility for your research: over $100 \mathrm{M}$ website views per year

At $\mathrm{BMC}$, research is always in progress.

Learn more biomedcentral.com/submissions 